Dave Rich

\title{
Why is the British Left Anti-Israel, and Why Does it Matter?
}

Jeremy Corbyn, the current leader of the British Labour Party, the figurehead of a left-populist backlash against neoliberalism, globalisation, and the centrist politics of former Labour Prime Ministers Tony Blair and Gordon Brown, first became a Member of Parliament in 1983; and when he did so, in fact before he even became an MP, Corbyn was a sponsor and supporter of a small anti-Zionist group on the radical left called the Labour Movement Campaign for Palestine (LMCP), which campaigned for the creation of a democratic, secular state of Palestine in place of Israel and pledged to oppose "manifestations of Zionism"1 in Labour. Its mission statement included the pledge that "The Labour Movement Campaign for Palestine will fight within the Labour Movement-and the Labour Party in particular-to eradicate Zionism."' Corbyn became a sponsor of the organisation early in 1983, not long after it was formed, and as an MP spoke regularly at its fringe meetings at party conferences and its other events. Israel's Labour Party was a particular target for its campaigns: it even brought out a special booklet on the subject, "to expose the monstrous myth of Labour Zionism's progressive or socialist nature." ${ }^{3}$ In 1985, the Students' Union of Sunderland Polytechnic, a college in the north east of England, decided to ban its Jewish Society due to that society's support for Zionism, which was considered by far-left students at the Polytechnic to be racist. The Students' Union was roundly condemned for what was felt by many to be an antisemitic act, but the Labour Movement Campaign for Palestine supported the Students' Union. It declared in its newsletter that while "it was a tactical mistake on the part of Sunderland Polytechnic Students' Union to ban an overtly Zionist Jewish Society ... We totally reject the assertion that Sunderland Poly's action was in any way antisemitic."4 The article went on to insist that anti-Zionism cannot possibly be antisemitic, because "Zionism is inherently racist" and a "colonising movement." In the same newsletter, Jeremy Corbyn, by now an MP, encouraged people to join the organisation, writing: "The Palestine question is one of the most important issues fac-

1 Labour Movement Campaign for Palestine, Newsletter (undated).

2 Ibid.

3 Labour Movement Campaign for Palestine, Labour Zionism: Socialist or Colonialist? (London: Labour Movement Campaign for Palestine, 1988).

4 Labour Movement Campaign for Palestine, Newsletter 2 (1985), emphasis in the original.

Ә OpenAccess. ( 2021 Armin Lange, Kerstin Mayerhofer, Dina Porat, Lawrence H. Schiffmann, published by De Gruyter. (cc) BY-NC-ND This work is licensed under the Creative Commons Attribution-NonCommercialNoDerivatives 4.0 International License. https://doi.org/10.1515/9783110671964-020 
ing the Labour movement," and "The Labour Movement Campaign for Palestine is the only campaign rooted in the Labour Movement whose platform really tackles the important issues in relation to this question. Its activities ought to be supported by every Labour Party member." 5 There were other pro-Palestinian groups active in the Labour Party at that time, including ones that supported a two-state solution, but for Corbyn, this particular group that opposed Israel's existence pledged to "eradicate Zionism" from the Labour Party and denied that the banning of a student Jewish society was an antisemitic act was "the only campaign" worth supporting.

All of this is to say that the problems relating to antisemitism and anti-Zionism that the Labour Party has experienced since Corbyn became its leader in September 2015 have deep roots. The Labour Movement Campaign for Palestine no longer exists, but its ideas are easy to find in today's Labour Party and across the British Left. Sympathy for the Palestinians and opposition to Israel has become the default position for many on the liberal and social democratic left: a defining marker of what it means to be progressive. Outright anti-Zionism is axiomatic for much of the Marxist left. This anti-Zionism has become part of a radical package of foreign policy stances that is glued together by opposition to American and Western power. Find out what somebody on the left thinks about Israel and Zionism and you can usually predict their views about a range of issues, such as who is to blame for jihadist terrorism and how to respond to it; the causes of Islamist extremism and of Islamophobia; Western military interventions overseas; and the wisdom of allying Britain to American power. For this part of the left, the Israeli-Palestinian conflict has come to symbolise much more than a struggle between two peoples for the same small strip of land on the eastern Mediterranean. Israel is seen as the epitome of Western domination, racism, and colonialism, and the Palestinians have come to represent all victims of Western power and militarism. "In our thousands, in our millions, we are all Palestinians," Corbyn told a rally in 2010. Or, as one of Corbyn's closest aides in the Labour leadership, Seumas Milne, put it when he was a Guardian journalist, Palestine has become "the great international cause of our time."6

This is the political culture where the current leadership of the British left finds its home. When I say "leadership," I mean this in both a formal and informal sense: the elected political leadership of the Labour Party, of course, but also the political culture that, right now, sets the tone and direction for the

5 Ibid.

6 S. Milne, "Palestinians have every right to defend themselves," filmed November 26, 2012, YouTube video, 3:58, https://www.youtube.com/watch?v=1EBjlQ-PI7 g. 
broader left. This political culture claims to be the true inheritor of "Old Labour," which dates back to the immediate post-war years when a Labour government created the National Health Service and the foundations of today's welfare state. But this is a false claim: really, this political culture is a legacy of the radical, youthful New Left of 1968, which was a rejection of that older Labour tradition. That 1968 New Left was more interested in identity than class. It saw the engine of revolution as residing in what was then called the Third World-now the Global South-rather than within Western proletariats. It rejected NATO and the Atlanticist foreign policy that came with it. It pursued single-issue campaigns on gender, sexuality, the environment, race, and disarmament, rather than seeking the broad social coalitions and mass movements on which the labour movement was traditionally based. This was the generation for whom the struggle to dismantle European empires in the name of anticolonialism was much more urgent and relevant than the fight against fascism-a fight that was won before most of them were even born.

Today it is easy for a leftist observer to look at Israel, a country allied to the United States, militarily powerful and economically successful, occupying land that the international community has decided belongs to the Palestinians, who in turn are stateless, weak, and poor-and draw the obvious political conclusions. It is taken for granted by much of today's left that Israel is a colonial settler state. This was not always the case; and it was only during the 1960s, the decade when this New Left began to radically re-think so many of the left's positions, that the hostility toward Israel and Zionism now common across much of the left began to take shape. Anti-colonialism, race, and the Cold War were formative in the New Left's development and created a framework that left Israel and Zionism on the wrong side of its political thinking. Shortly before the Six Day War, New Left Review, the leading intellectual journal of the New Left in Britain, published an article by Che Guevara in which he contrasted Israel, "backed by the imperialists," with its enemies, "the progressive countries" of the Middle East. ${ }^{7}$ In its next edition, following the war, New Left Review carried an interview with Isaac Deutscher, the acclaimed biographer of Trotsky and author of The Non-Jewish Jew, in which Deutscher scathingly described the war as part of "a tremendous political, ideological, economic, and military offensive over a vast area of Asia and Africa” by "American imperialism, and the forces associated with it and supported by it." ${ }^{\text {This }}$ idea that Israel was implanted in the Middle

7 C. Guevara, "Vietnam Must not Stand alone,” New Left Review 43 (May-June 1967): 79-91. 8 I. Deutscher, “On the Israeli-Arab War," interview, New Left Review 44 (July-August 1967): $30-45$. 
East by Western colonialism was also a common theme in the propaganda of the PLO from its founding in 1964 and is still heard regularly today in statements by Palestinian leaders. Just recently in Ramallah, Mahmoud Abbas said in a speech that "Israel is a colonialist venture which is unconnected to Jews-they were exploited in order to facilitate this project, using terms such as the Promised Land." "9

This anticolonial analysis of Israel's founding denies the authentic, historic Jewish connection to the land of Israel or their agency in the creation of the Jewish State. Jews and their national aspirations are relegated to being mere tools of a vast Western conspiracy against the Palestinians, or against the Arab world, or against all Muslims, depending on who is propagating this particular theory. It also connects the modern left to older Marxist thinking that the Jews are not a genuine nation or people. Marxist theory has never been comfortable with the idea that Jews form a nation or that Zionism is an authentic movement of national liberation. Marx himself, Bruno Bauer, Abram Leon, and other Marxist and socialist writers grappled with this question over many decades, but the fundamental Marxist view of Jews and Judaism has changed little: Jews are not an authentic national people, Zionism is counter-revolutionary, and both will become redundant with the onward march of history.

If this kind of anticolonial anti-Zionism is a sort of conspiracy theory in which the antisemitism is only implicit, and in which the Jewish masses are portrayed as victims of a conspiracy by Jewish elites in the Zionist movement, there are other conspiracy theories about Zionism that deploy much more explicit antisemitism. The antisemitic treatment of Zionism in Soviet propaganda, for example, that developed during the last years of Stalin's life, outlived Stalinism and intensified after 1967, both for domestic consumption and as part of Soviet outreach to the European left and to Third World countries. Articles accusing Israel of racism and colonialism, comparing Zionism to Nazism, and using traditional antisemitic tropes were published with increasing regularity in the Soviet media and then translated into English and distributed in pamphlet form in the West. The image of a global Zionist conspiracy with Israel as its tool, powered by Jewish wealth and responsible for war and economic exploitation, is strikingly similar to older antisemitic conspiracy theories about Jews. This is not a coincidence: the rhetorical connection of Zionism to colonialism and imperialism allows and encourages the idea that Zionism is a global network of power,

9 J. Khoury, “Abbas Declares Oslo Accords Dead: ‘Trump’s Peace Plan Is a Slap, We'll Slap Back',” Haaretz, January 15, 2018, https://www.haaretz.com/middle-east-news/palestinians/ abbas-declares-oslo-accords-dead-trump-s-peace-plan-is-a-slap-1.5730759. 
used to prosecute wars and generate financial gain, much as the fabled Jewish conspiracy was alleged to do. This Soviet antisemitism percolated through anti-colonial politics to influence the anti-Zionist discourse to which Western leftists were increasingly exposed.

This is a form of antisemitism that mimics and borrows from traditional antisemitic themes, but it is nevertheless a specific left-wing variant that manifests in specifically left-wing ways. There are other features of left-wing hostility to Zionism and to Israel that can have antisemitic consequences. For example, Jews seeking to operate in left-wing spaces may be asked to declare their position on the Israeli-Palestinian conflict, or their attitude toward settlements, or to sign statements opposing the occupation. Jewish students often complain about being subjected to this kind of questioning; recently, Amnesty International cancelled a meeting of the Jewish Leadership Council on their premises in London on the grounds that, according to Amnesty, the JLC supports settlements and opposes boycotts of them. This is a political test solely for Jews, and as such it is discriminatory, but it is more than that: it is also a subtle, left-wing version of the old antisemitic loyalty test, in which Jews are suspected of having more loyalty to other Jews than to the nation in which they live or the political movement for which they express support. The subtext to this left-wing variant of the old antisemitic charge of Jewish disloyalty is a regret that Jews betrayed their true revolutionary calling by choosing Zionism. Marxism first encountered Zionism as a competitor for the affections of Jews across Russia and Europe a century ago. For various reasons Zionism won that particular argument, and some on the left have never forgiven Jews for choosing nationalism instead of putting their hopes and dreams into the universal liberation of all humanity.

The reason why Jews are treated differently by so many on the left comes down to the question of power. This is not just about the relative power disparity between Israel and the Palestinians, although that is an important factor. It is also about how many on the left see the position of Jews within their own societies; and this in turn relates to left-wing understandings and definitions of racism. Racism is largely understood as a prejudice determined by skin colour, deployed by the structures of power and inequality in society, that manifests as socio-economic discrimination and exclusion. It follows that those who have power cannot be victims of racism, while those without power cannot be racist. This same strand of left-wing thought sees Jews as white, wealthy, integrated, and close to, or part of, the political and financial elites that wield ultimate power in Western societies. Therefore, logically, Jews cannot suffer racism.

However, antisemitism operates not through concrete discrimination but through ideas, myths, and conspiracy theories that encourage hatred of Jews precisely because they are seen as powerful. It is found in the Protocols of the Elders 
of Zion, Holocaust Denial, and the blood libel. And this is precisely the kind of antisemitism that has the potential to appeal to people on the left, because it claims to be anti-hegemonic, anti-capitalist, and anti-imperialist: all things that appeal to left-wing people. During the Left's formative years, when socialist and Marxist thinkers were developing their critique of capitalism and international finance, a strand of thinking emerged that drew on existing antisemitic conspiracy theories associating Jews with capitalism to argue that the working classes were oppressed by a specifically Jewish network of power and wealth. Now, most left-wing people are not antisemitic and, overall, the Left's history of opposing antisemitism outweighs its history of indulging it; nevertheless, from its earliest days, the Left has had its own particular form of antisemitism that is not fascist or xenophobic but is a distorted reading of the Left's commitment to freedom and emancipation. It is, in that well-known phrase, the "socialism of fools"; and in a time when mainstream politics on the left and right seems to be particularly foolish, this kind of antisemitism is currently having one of its periodic moments of popularity.

There is one fundamental difference between left and right that should not be glibly dismissed: most of Israel's left-wing critics, even those who use antisemitic language and ideas, are avowedly anti-racist. Many are Jews and act in the name of what they believe to be Jewish values. This makes opposition to Israel fundamentally different from the antisemitism that affected European Jewry in past centuries; but the fact that left-wing anti-Zionists sincerely believe themselves and all their comrades to be anti-racist makes it much harder for them to see the antisemitism in their movement, precisely because they believe it cannot exist there. Instead, they assume that any antisemitism to be found on the left is caused by right-wing people who have wandered into the wrong party by accident, or by left-wing people who have mistakenly read something antisemitic and not recognised it as an alien politics.

To illustrate this point I will conclude with one of the most striking visual images from Jeremy Corbyn's time as Labour Party leader. The problem of antisemitism in the Labour Party peaked in April 2016, when Labour MP Naz Shah and former Labour Mayor of London Ken Livingstone were both suspended from the party for alleged antisemitic statements. This turned a minor scandal into a fullblown crisis for Labour. Three days later, Corbyn came under intense pressure to speak out about this problem of antisemitism in his party, and he chose to do so at London's May Day rally, an annual left-wing event to mark International Workers' Day. However, the way he did it, and the political context he gave to antisemitism highlight many of the problems I have described.

"Addressing the marchers before they set off from Clerkenwell Green, a traditional site for radical protests, Corbyn said: 


\begin{abstract}
We also have to stand up against racism in any form whatsoever in our society. We've stood in this green and Trafalgar Square and many other places, against apartheid South Africa. Eventually apartheid South Africa was defeated. We stood in solidarity with many in the USA, fighting for civil rights during the '60s and '70s. We stand in solidarity now against the growth of the far right across Europe, that are more interested in blaming migrant workers, blaming victims of war who are refugees, than facing up to the reality that we're all human beings living on one planet, and you solve problems by human rights, humanity and justice and respect, not by blaming minorities. And so we stand absolutely against antisemitism in any form. We stand absolutely against racism in any form. We stand united as a Labour movement, recognising our faith diversity, our ethnic diversity, and from that diversity comes our strength. That is the strength of our movement. ${ }^{10}$
\end{abstract}

This is Jeremy Corbyn's understanding of antisemitism-and it is a typical view. He sees it only as a far-right phenomenon: part of a broader xenophobic politics that is against diversity and stigmatises refugees and minorities. He opposes it because he opposes fascism and as part of his internationalist politics that opposed apartheid and racial inequality overseas."11

Yet in a remarkable visual irony, many of the marchers who stood and listened to the Corbyn that day carried banners with images of Joseph Stalin. Now, Stalin was, amongst other things, an antisemite, and the Soviet bloc practiced antisemitism as state policy. In the late 1940s, Stalin crushed Jewish political and cultural activity in the Soviet Union. In the early 1950s, he oversaw antisemitic purges of Jewish Communist Party figures in the Soviet Union and its satellite states in Eastern Europe. 2018 marked the fiftieth anniversary of the antisemitic campaign in Communist Poland in 1968 that, while dressed up as "antiZionism" and decrying overt antisemitism, forced half of Poland's remaining Jews to flee the country. It is likely that Stalin's death in 1953 prevented the mass round-up and deportation-and possibly even genocide-of Soviet Jews. Jews around the world spent decades campaigning for the freedom of Soviet Jewry. Yet the historical amnesia and political ignorance of the British Left is so profound that the leader of the Labour Party can stand in front of a mass of Stalinist flags and, with a straight face, claim that "we stand absolutely against antisemitism in any form."12 And until this changes, the British Left will continue to be a place where antisemitism of one particular form-a specifically left-wing form-finds a home.

10 Ruptly, “We stand absolutely against anti-Semitism'-Corbyn leads London May Day rally,” filmed May 1, 2016, YouTube video, 2:06, https://www.youtube.com/watch?v=er_lhpTKMHI.

11 This section is taken from the author's book The Left's Jewish Problem: Jeremy Corbyn, Israel and Anti-Semitism (London: Biteback Publishing, 2016), 132-3.

12 Ruptly, “We stand absolutely against anti-Semitism,." 
Dr. Dave Rich is Director of Policy at the Community Security Trust and Associate Research Fellow at the Pears Institute for the Study of Antisemitism, Birkbeck, University of London. He is author of The Left's Jewish Problem: Jeremy Corbyn, Israel and Antisemitism (Biteback, 2016 \& 2018) and his research areas and publications cover different varieties of antisemitism, anti-Zionism, political and religious extremism, Holocaust denial and hate crime.

\section{References}

Deutscher, Isaac. "On the Israeli-Arab War.” Interview. New Left Review 44 (July-August 1967): $30-45$.

Guevara, Che. "Vietnam Must not Stand alone." New Left Review 43 (May-June 1967): $79-91$.

Khoury, Jack. “Abbas Declares Oslo Accords Dead: ‘Trump’s Peace Plan Is a Slap, We'll Slap Back'.” Haaretz, January 15, 2018. https://www.haaretz.com/middle-east-news/pales tinians/abbas-declares-oslo-accords-dead-trump-s-peace-plan-is-a-slap-1.5730759.

Labour Movement Campaign for Palestine. Labour Zionism: Socialist or Colonialist? London: Labour Movement Campaign for Palestine, 1988.

Labour Movement Campaign for Palestine. Newsletter. Undated. Labour Movement Campaign for Palestine. Newsletter 2 (1985).

Milne, Seumas. "Palestinians have every right to defend themselves." Filmed November 26, 2012. YouTube video, 3:58. https://www.youtube.com/watch?v=1EBjlQ-PI7 g.

Rich, Dave. The Left's Jewish Problem: Jeremy Corbyn, Israel and Anti-Semitism. London: Biteback Publishing, 2016.

Ruptly. "We stand absolutely against anti-Semitism'-Corbyn leads London May Day rally." Filmed May 1, 2016. YouTube video, 2:06. https://www.youtube.com/watch?v=er_ IhPTKMHI. 